\title{
Synthesis, Structural Calculations and Molecular Docking Studies of a Novel Uracil Derived Organic Molecule
}

\author{
Yeni Urasil Türevi Organik Bir Molekülün Sentezi, Yapısal \\ Hesaplamaları ve Moleküler Modelleme Çalışmaları
}

\author{
Research Article
}

Gamze Koz

Bursa Technical University, Department of Chemistry, Faculty of Natural Sciences, Architecture and Engineering, Bursa, Turkey.

\section{A B S T R A C T}

\begin{abstract}
A novel uracil derived compound, (E)-5-((3-chloro-2-hydroxybenzylidene)amino) pyrimidine-2,4(1H,3H)Adione, was synthesized and characterized using spectroscopic techniques. The interaction of the molecule with DNA was explored using computational methods which revealed that the molecule could act as a groove binder. The physicochemical properties of the molecule such as frontier molecule orbitals and chemical reactivity parameters were also investigated.
\end{abstract}

\section{Key Words}

Uracil, Schiff base, DNA binding, groove binder, molecular modelling.

\section{öz}

rasil türevi yeni bir bileşik, (E)-5-((3-klor-2-hidroksibenziliden)amino)pirimidin-2,4 (1H,3H)-dion, sentezlendi ve spektroskopik yöntemler kullanılarak yapı tayini gerçekleştirildi. Molekülün DNA ile olan etkileşimi, bilgisayar destekli yöntemler ile araştırıldı ve oluk bağlayıcı olarak davranabileceği belirlendi. Bileşiğin, molekül orbitalleri ve kimyasal reaktivite parametreleri gibi fizikokimyasal özellikleri incelendi.

\section{Anahtar Kelimeler}

Urasil, Schiff bazı, DNA bağlanma, oluk bağlayıcı, moleküler modelleme.

Article History: Received: Mar 12, 2018; Revised: May 17, 2018; Accepted: Jul 6, 2018; Available Online: Oct 4, 2018.

DOI: $10.15671 /$ HJBC.2018.244

Correspondence to: G. Koz, Bursa Tech. Uni., Dept of Chem., Fact. of Natural Sci., Architecture and Engineering, Bursa, Turkey. 


\section{INTRODUCTION}

D NA has a critical role in recent drug development processes. As it is responsible for both replication and transcription, DNA interacting small organic molecules have a high potential as a drug candidate. There is a variety of biologically active molecule which is known to strongly interact with DNA and used for the treatment of cancer, AIDS and malaria [1]. The electrostatic interactions, intercalation and groove binding are the ways of small molecules to interact with DNA [2-6]. The groove binders such as 4,6-diamidino-2-phenyl-indole (DAPI) in Figure 1 are the molecules that bind to the minor or major grooves of DNA and play a key role in drug research.

Uracil is one of the four nucleobases in RNA 5 -aminouracil is an attractive molecule in terms of DNA binding studies as a result of its ability to form strong hydrogen bonds, multifunctional structure of lactim-lactam tautomer and functional group diversity which are all suitable for chemical derivatizations [7].

During our theoretical studies on the determination of uracil derived small organic molecules with high DNA binding affinity, we have found that a novel molecule (3-Cl-5-AAU) derived from 5-aminouracil and 3-chloro-2hydroxybenzaldehyde has the potential to act as a groove binder. As a result, the molecule, 3- $\mathrm{Cl}-5$ AAU, was synthesized, characterized and further investigated in terms of some structural features such as frontier molecular orbitals, electrostatic potential map, chemical reactivity and DNA interactions.

\section{MATERIALS and METHODS Chemistry}<smiles>N=C(N)c1ccc(-c2cc3ccc(C(=N)N)cc3[nH]2)cc1</smiles>

DAPI
All reagents were obtained from commercial sources and used without further purification. Silica gel $F_{254}$ (Merck 5554) precoated plates were used for thin layer chromatography. Infrared spectrum was recorded on a NICOLET - IS50 FTIR. ${ }^{1} \mathrm{H}$ NMR and ${ }^{13} \mathrm{C}$ NMR spectra were carried out using a $400 \mathrm{MHz}$ Bruker NMR spectrometer at ambient temperature. The elemental analysis was performed on a Costech ECS 4010 analyzer. Melting point was recorded with an electro thermal digital melting points apparatus.

\section{Synthesis of (E)-5-((3-chloro-2-} hydroxybenzylidene)amino)pyrimidine-2,4(1H,3H)dione

5-aminouracil (112 mg, $1 \mathrm{mmol}$ ) and 3-chloro-2hydroxybenzaldehyde (172 mg, $1.1 \mathrm{mmol}$ ) were placed in a flask with $20 \mathrm{ml}$ ethanol and a few drops of glacial acetic acid. This mixture was refluxed for several hours until the reaction was completed. Then the yellow precipitate was filtered off, washed with hot ethanol and air dried.

Yield: $259 \mathrm{mg}$ (97\%); Mp: $>250^{\circ} \mathrm{C}$; IR (ATR): $=3194,3069,2911,1709,1663,1595,1448,1424$,

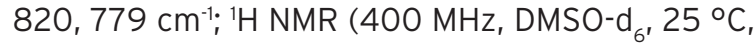
TMS) (ppm): $6.93(\mathrm{t}, \mathrm{J}=5.2 \mathrm{~Hz}, 1 \mathrm{H}), 7.46(\mathrm{~d}, \mathrm{~J}=5.2$ $\mathrm{Hz}, 1 \mathrm{H}), 7.49(\mathrm{~d}, \mathrm{~J}=5.2 \mathrm{~Hz}, 1 \mathrm{H}), 7.98(\mathrm{~s}, 1 \mathrm{H}), 9.48$ $(\mathrm{s}, 1 \mathrm{H}), 11.49$ (bs, 2H) ${ }^{13} \mathrm{C}$ NMR $\left(400 \mathrm{MHz}, \mathrm{DMSO}^{-\mathrm{d}_{6^{\prime}}}\right.$ $25^{\circ} \mathrm{C}$, TMS): $118.9,119.4,120.0,120.5,130.8,132.1$, 138.0, 149.9, 155.6, 160.3, 160.9. Anal. Calcd. for C11H8CIN3O3: C, 49.73; H, 3.04; N, 15.82\%. Found: C, 49.70; H, 3.04; N, 15.81\%.

\section{DFT Studies}

All quantum chemical calculations in this work were carried out using Gaussian 09 software packed [8]. The structures of the molecule $(3-\mathrm{Cl}-$ $5 A A U)$ was optimized using density functional

Figure 1. Chemical structure of some DNA groove-binding agents. 
theory (DFT) with the Becke-Lee-Yang-Parr functional (B3LYP) method [9] with 6-311++G(d,p) basis set. Harmonic frequencies of the structures were calculated at the same method and basis sets to find local minima. The optimized structural parameters were used for all of the docking and physicochemical calculations in this study.

\section{Chemical Reactivity}

In order to obtain a detailed information about reactivity of 3-Cl-5-AAU, chemical reactivity parameters, chemical hardness $(\eta)[10]$, chemical potential $(\mu)[10]$, and electrophilicity index $(\omega)$ [11] were evaluated from HOMO and LUMO energies. On the other hand, dipole moment is a useful index for the description of interactions between two chemical species. Therefore, the larger the dipole moment is, the stronger the van der Waals interaction will be. The chemical hardness $(\eta)$ and the chemical potential $(\mu)$ are fundamental indicators of the stability and overall reactivity of a chemical system. The electrophilicity index $(\omega)$ allows quantitative description of the global electrophilic or nucleophilic nature of chemical species, physically signifying the propensity of chemical species to accept electrons.

\section{Molecular Docking}

Molecular docking studies were performed using Autodock Vina program [12]. The crystal structure of DNA was obtained from the Protein Data Bank (PDB ID: 1BNA). The PDB format of 3-Cl-5-AAU was obtained by converting its 'out' files using Autodock software. Docking was performed to find the most stable and favorable orientation.
Visualization of connected systems was performed using Discovery Studio 3.5 software. The binding sites were centered on the DNA, and a grid box was created with $60 \times 60 \times 60$ points and a $0.375 \AA$ grid spacing in which almost the entire macromolecule was involved. All other parameters were kept at their default values.

\section{RESULTS and DISCUSSION}

The target molecule, 3-Cl-5-AAU, was obtained in high yield with a simple acetic acid catalyzed Schiff base reaction between 5 -aminourasil and 3-chloro-2-hydroxybenzaldehyde in ethanol (Scheme 1). The structure of 3-Cl-5-AAU was fully characterized using spectroscopic methods (FTIR, ${ }^{1} \mathrm{H}$ NMR and ${ }^{13} \mathrm{C}$ NMR) and elemental analysis.

The most stable molecular structure of $3-\mathrm{Cl}$ 5-AAU was optimized by the DFT/B3LYP method with $6-311++G(d, p)$ basis set. The bond parameters (bond lengths and angles) of the molecule are listed in Table 1. The optimized structure with numbering of atoms is shown in Figure 2.

Generally, the bond parameters calculated with $6-311++G(d, p)$ basis set are very close to experimental values for small organic molecules in the literature [13]. The most important bonds of uracil compounds are the two carbonyl (C1-01 / C2-02) double bonds. The bond lengths of these carbonyl groups were calculated at ca. 1.212 and $1.218 \AA$. In addition, the $\mathrm{N}-\mathrm{H}$ bonds of the molecule were performed at $1.010 \AA$. The imine bond length (C5-N3) was calculated at ca. 1.297 $\AA$. The C-C bond lengths of the phenyl ring were in the ranges<smiles>O=Cc1cccc(Cl)c1O</smiles><smiles>Nc1c[nH]c(=O)[nH]c1=O</smiles>

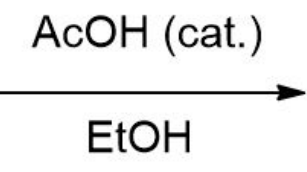<smiles>O=c1[nH]cc(/N=C/c2cccc(Cl)c2O)c(=O)[nH]1</smiles>

3-CI-5-AAU

$97 \%$ yield 
Table 1. Selected geometric parameters of 3-Cl-5-AAU molecule.

\begin{tabular}{|c|c|c|c|}
\hline Bond lengths $(\AA)$ & DFT & Bong angles $\left(^{\circ}\right)$ & DFT \\
\hline $\mathrm{C} 1-01$ & 1.211 & $\mathrm{O} 1-\mathrm{C} 1-\mathrm{N} 2$ & 124.4 \\
\hline $\mathrm{C} 1-\mathrm{N} 2$ & 1.384 & $\mathrm{C} 1-\mathrm{N} 2-\mathrm{C} 2$ & 128.9 \\
\hline $\mathrm{C} 2-\mathrm{N} 2$ & 1.406 & $\mathrm{~N} 2-\mathrm{C} 2-\mathrm{O} 2$ & 119.6 \\
\hline $\mathrm{C} 2-\mathrm{O} 2$ & 1.218 & $\mathrm{C} 4-\mathrm{C} 3-\mathrm{N} 3$ & 117.1 \\
\hline $\mathrm{C} 2-\mathrm{C} 3$ & 1.475 & C3-N3-C5 & 124.4 \\
\hline C3-C4 & 1.362 & $\mathrm{C} 5-\mathrm{C} 6-\mathrm{C} 7$ & 118.9 \\
\hline $\mathrm{C} 4-\mathrm{N} 1$ & 1.368 & $\mathrm{C} 6-\mathrm{C} 7-\mathrm{C} 8$ & 121.1 \\
\hline $\mathrm{C} 3-\mathrm{N3}$ & 1.393 & C9-C10-C11 & 121.1 \\
\hline $\mathrm{C} 5-\mathrm{N} 3$ & 1.296 & $\mathrm{C} 10-\mathrm{C} 11-\mathrm{O} 3$ & 119.7 \\
\hline $\mathrm{C} 5-\mathrm{C} 6$ & 1.452 & $\mathrm{C} 11-\mathrm{O} 3-\mathrm{H}$ & 106.7 \\
\hline $\mathrm{C} 6-\mathrm{C} 7$ & 1.406 & $\mathrm{C} 9-\mathrm{C} 10-\mathrm{Cl}$ & 119.9 \\
\hline $\mathrm{C} 9-\mathrm{C} 10$ & 1.387 & & \\
\hline $\mathrm{C} 11-\mathrm{O} 3$ & 1.337 & & \\
\hline $\mathrm{O} 3-\mathrm{H}$ & 0.993 & & \\
\hline $\mathrm{C} 10-\mathrm{Cl} 1$ & 1.751 & & \\
\hline $\mathrm{N} 1-\mathrm{H}, \mathrm{N} 2-\mathrm{H}$ & 1.010 & & \\
\hline
\end{tabular}

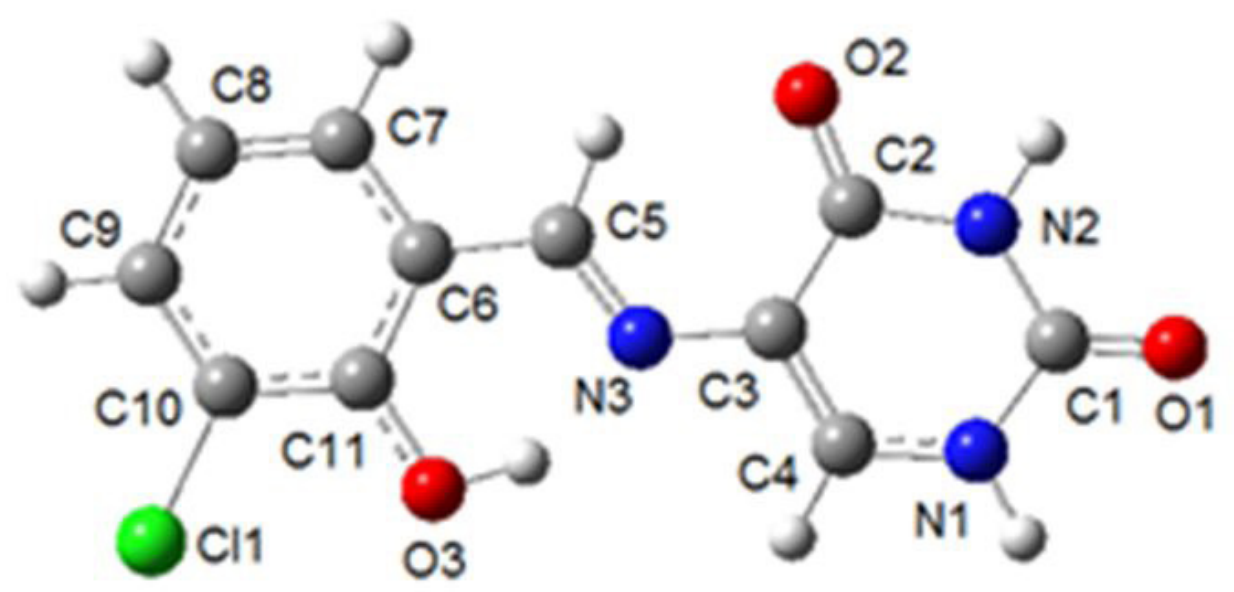

Figure 2. The most stable optimized molecular structure of 3-CI-5-AAU.

of $1.387-1.406 \AA$ while the $\mathrm{C} 10-\mathrm{Cl}$ bond length was calculated at ca. $1.751 \AA$. All atoms were on the same plane, that is, the molecule is planar.

Highest Occupied Molecular Orbital (HOMO) and Lowest Unoccupied Molecular Orbital (LUMO) are very significant parameters to determine reactivity of molecules. The frontier molecular orbital (HOMO and LUMO) shapes of 3-Cl-5-AAU were determined using DFT/B3LYP method with $6-311++G(d, p)$ basis set. The energy band gap between the HOMO and LUMO for this molecule is given in Figure 3.

The calculated HOMO and LUMO energies of the molecule were -6.392 and $-2.502 \mathrm{eV}$, respectively, and thus, the energy difference was $3.890 \mathrm{eV}$. Using the HOMO and LUMO energy 


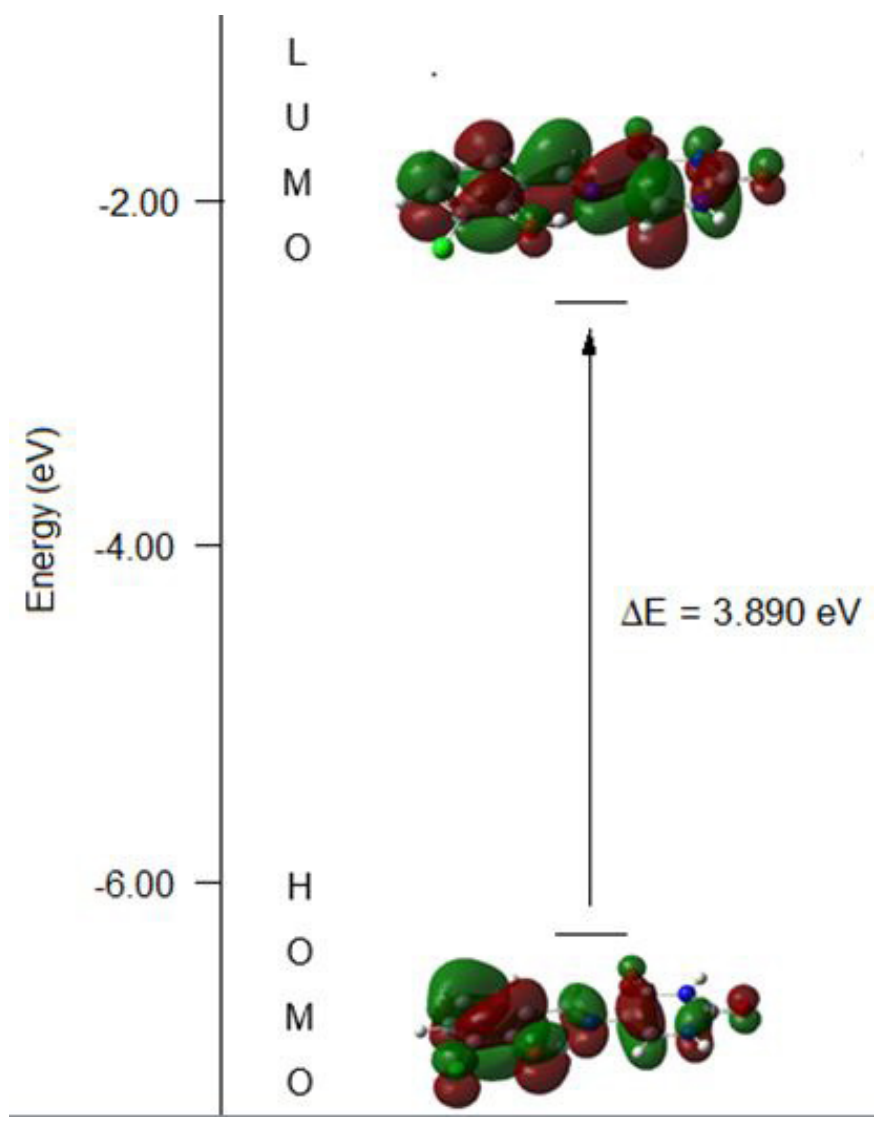

Figure 3. Frontier molecular orbitals of 3-Cl-5-AAU with the energy gap.

values, the global chemical reactivity descriptors of the molecule are defined as: hardness, $\eta=(1-$ A) $/ 2=1.945$, electronegativity, $\chi=(I+A) / 2=$ -4.447, softness $S=0.257$ and electrophilicity index $\omega=\mu^{2} / 2=5.084$ where $A\left(-E_{\text {Lumo }}\right)$ and I $\left(-\mathrm{E}_{\text {номо }}\right)$ are the ionization potential and electron affinity. These results are presented in Table 2. Such quantities have been used to understand toxicity in terms of reactivity and site selectivity [14].

The reactive behavior of the molecule is visualized with the help of three-dimensional molecular electrostatic potential (MEP) surface. The surfaces of the molecule was plotted over an optimized electronic structures using B3LYP/6$311++G(d, p)$ as shown in Figure 4.

Molecular electrostatic potential (MEP) is used for investigating the chemical reactivity of a molecule and represented by different colors. The maximum negative region with preferred site for electrophilic reactivity is indicated by blue and nucleophilic reactivity is indicated by yellow
[15]. The MEP map of 3-Cl-5-AAU illustrates that the negative potential sites in the whole molecule are on protons attached to the nitrogen atoms of the uracil ring and also mainly on the N1 proton. These theoretical calculations are consistent both with spectroscopic and experimental results. As the electron density around a nucleus decreases, it is said to be deshielded and resonates at higher ppm values in a ${ }^{1} \mathrm{HNMR}$ experiment. The $\mathrm{NH}$ protons of 3-Cl-5-AAU molecule are also deshielded and resonated at $11.49 \mathrm{ppm}$. These theoretical calculations are also compatible with some experimental studies related to reactivity of uracil derivatives in $\mathrm{N}$-alkylation reactions [16]. According to those studies, N1 atom of uracil was easily alkylated first and protecting group strategy was used in the need of selective N2 alkylations.

There has been increasing interest in the usage of docking methods to study the binding of molecules to DNA. The structure of 3-Cl-5-AAU was optimized using density functional theory (DFT) with the Becke-Lee-Yang-Parr functional 
Table 2. HOMO and LUMO energies, the energy gap ( $\Delta \mathrm{E})$, absolute electronegativity $(\chi)$, chemical potential $(\mu)$, chemical hardness $(\eta)$, softness $(S)$ and electrophilicity index $(\omega)$ of 3-Cl-5-AAU using B3LYP/6-311++G(d,p) level.

\begin{tabular}{ll}
\hline Global reactivity descriptors & 3-Cl-5-AAU \\
\hline$E(H O M O, e V)$ & -6.392 \\
\hline$E(L U M O, e V)$ & -2.502 \\
\hline$\Delta E(e V)$ & 3.890 \\
\hline$\chi$ & -4.447 \\
\hline$\mu$ & 4.447 \\
\hline$S$ & 1.945 \\
\hline$\omega$ & 0.257 \\
\hline
\end{tabular}

\section{$-4.194 \mathrm{e}-2$}

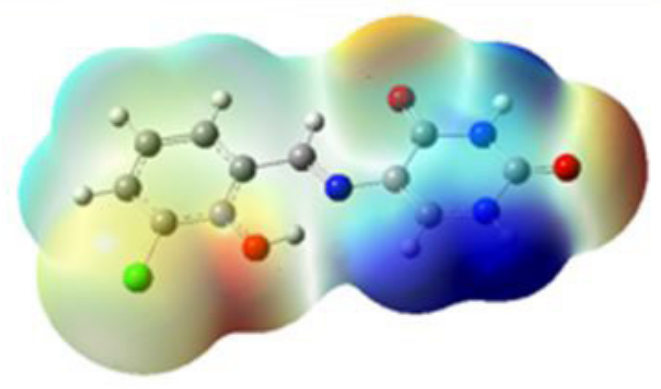

Figure 4. The total electron density mapped with molecular electrostatic potential surface of 3-CI-5-AAU.

(B3LYP) method. Docking was performed to find the most stable and favorable orientation and the most favorable docked orientation is depicted in Figure 5.

The related values of hydrogen bonding interactions such as distance and free binding energy of the most stable docked orientation of 3-Cl-5AAU was depicted in Table 3.

According to these results, 3-Cl-5-AAU molecule was mainly stabilized by three hydrogen bonding interactions and it moderately interacts with DNA adjacent to the $G / C$ rich sequence of the minor groove. The binding free energy of the docked structure was computed to be 33.472 $\mathrm{kJ}^{\mathrm{mol}}{ }^{-1}$.

In conclusion, a novel molecule, 3-Cl-5AAU, was synthesized and fully characterized using different spectroscopic methods such as FTIR, ${ }^{1} H$ NMR, ${ }^{13} \mathrm{C}$ NMR and elemental analysis. DFT calculations were performed to analyze the frontier molecular orbitals and chemical reactivity of the molecule. In silico methods were used to determine the binding potential of this molecule to DNA. The docking analysis revealed that the binding of the compound with DNA preferably takes place in the minor groove and the interaction strength through hydrogen bonding is encouraging for a small organic molecule. To the best of our knowledge, this is the first theoretical and experimental study related to the structural features of such uracil compounds. Design and synthesis of similar uracil derived compounds are under investigation in our laboratories for further in vitro activity studies. 
Figure 5. Computational docking model illustrating the interactions between DNA (PDB code: 1BNA) and 3-CI-5-AAU.
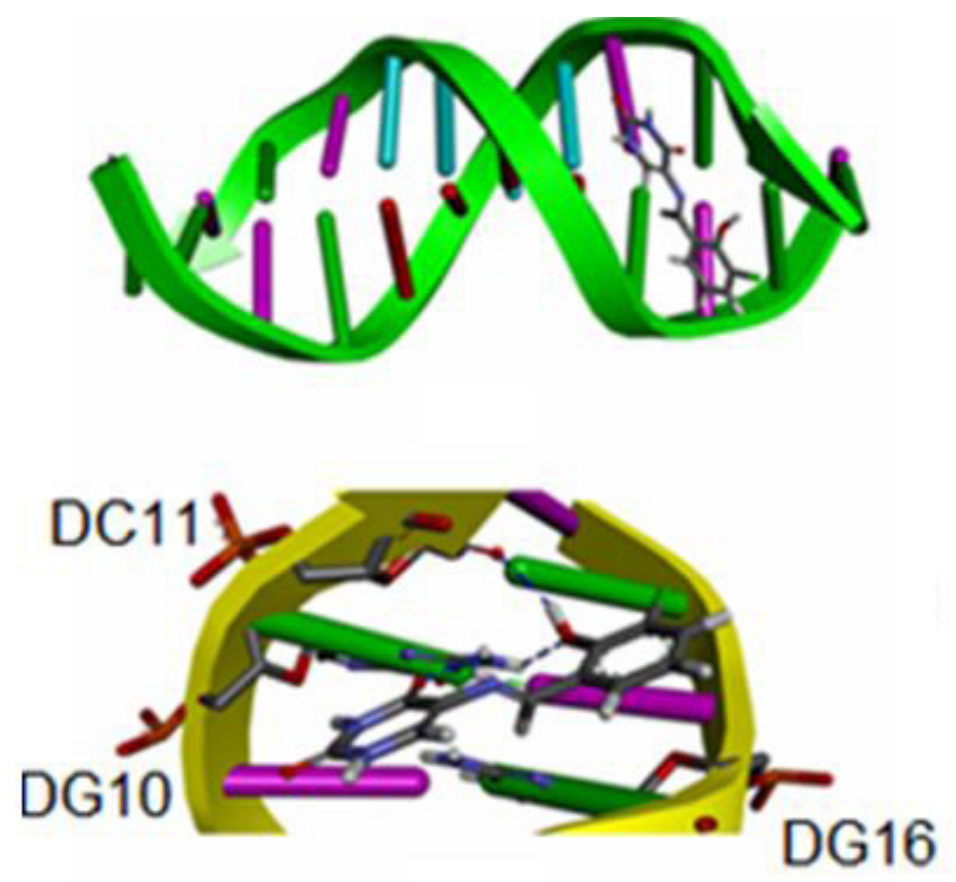

Table 3. Hydrogen bonding interactions and the binding free energy of the most stable docking conformation for 3-Cl-5-AAU docked into DNA.

\begin{tabular}{|c|c|c|c|}
\hline $\begin{array}{l}\text { Donor } \\
(\mathrm{D}-\mathrm{H})\end{array}$ & $\begin{array}{l}\text { Acceptor } \\
(\mathrm{H} \times \times \times \times A)\end{array}$ & $\begin{array}{l}\text { Distance } \\
(\mathrm{H} \times \times \times \times \mathrm{A}, \AA)\end{array}$ & $\begin{array}{l}\Delta \mathrm{G}_{\text {bind }}{ }^{*} \\
\left(\mathrm{~kJ} \cdot \mathrm{mol}^{-1}\right)\end{array}$ \\
\hline $\mathrm{O} 3 \mathrm{H}$ & $\begin{array}{l}02 \\
\text { (DC11-DNA,chainA) }\end{array}$ & 2.16 & \\
\hline $\begin{array}{l}\mathrm{N} 2 \mathrm{H} 21 \\
\text { (DG10-DNA,chainA) }\end{array}$ & $\mathrm{O3}$ & 2.40 & -33.472 \\
\hline $\begin{array}{l}\mathrm{N} 2 \mathrm{H} 22 \\
\text { (DG10-DNA,chainA) }\end{array}$ & $\mathrm{O} 2$ & 2.70 & \\
\hline
\end{tabular}

\section{Acknowledgements}

Bursa Technical University and Prof. Ömer Koz are gratefully acknowledged for their support. Asst. Prof. Yunus Kaya is acknowledged for molecular docking studies.

\section{References}

1. G. Bischoff, S. Hoffmann, DNA-Binding of Drugs Used in Medicinal Therapies, Current Medicinal Chemistry, 9 (2002) 321-348.

2. A. Hartwig, The role of DNA repair in benzene-induced carcinogenesis, Chem.-Biol. Interact., 184 (2010) 269272.
3. G. P. Mantle, V. F. Marquis, A. R. Manderville, B. Squillaci and A. Pfohl-Leszkowicz, Structures of Covalent Adducts between DNA and Ochratoxin A: A New Factor in Debate about Genotoxicity and Human Risk Assessment, Chem. Res. Toxicol., 23 (2010) 89-98.

4. S. Kashanian, S. Askari, F. Ahmadi, K. Omidfar, S. Ghobadi and A. F. Tarighat, In Vitro Study of DNA Interaction with Clodinafop-Propargyl Herbicide, DNA Cell Biol., 27 (2008) 581-586.

5. A. F. Tanious, Y. D. Ding, A. D. Patrick, R. R. Tidwell and D. W. Wilson, A New Type of DNA Minor-Groove Complex: Carbazole Dication $\$ D N A$ Interactions, Biochemistry, 36 (1997) 15315-15325.

6. F. Ahmadi and F. Bakhshandeh, In Vitro Study of Damaging Effects of 2,4-Dichlorophenoxyacetic Acid on DNA Structure by Spectroscopic and Voltammetric Techniques, DNA Cell Biol., 28 (2009) 527-533. 
7. R. M. Shaker, M. A. Elrady, K. U. Sadek, Synthesis, reactivity, and biological activity of 5-aminouracil and its derivatives, Mol. Divers., 20 (2016) 153-183.

8. M. J. Frisch, G. W. Trucks, H. B. Schlegel, G. E. Scuseria, M. A. Robb, J. R. Cheeseman, Jr. J. A. Montgomery, T. Vreven, K. N. Kudin, J. C. Burant, J. M. Millam, S. S. Iyengar, J. Tomasi, V. Barone, B. Mennucci, M. Cossi, G. Scalmani, N. Rega, G. A. Petersson, H. Nakatsuji, M. Hada, M. Ehara, K. Toyota, R. Fukuda, J. Hasegawa, M. Ishida, T. Nakajima, Y. Honda, O. Kitao, H. Nakai, M. Klene, X. Li, J. E. Knox, H. P. Hratchian, J. B. Cross, V. Bakken, C. Adamo, J. Jaramillo, R. Gomperts, R. E. Stratmann, O. Yazyev, A. J. Austin, R. Cammi, C. Pomelli, J. W. Ochterski, P. Y. Ayala, K. Morokuma, G. A. Voth, P. Salvador, J. J. Dannenberg, V. G. Zakrzewski, S. Dapprich, A. D. Daniels, M. C. Strain, O. Farkas, O. D. K. Malick, A. D. Rabuck, K. Raghavachari, J. B. Foresman, J. V. Ortiz, Q. Cui, A. G. Baboul, S. Clifford, J. Cioslowski, B. B. Stefanov, G. Liu, A. Liashenko, P. Piskorz, I. Komaromi, R. L. Martin, D. J. Fox, T. Keith, M. A. AlLaham, C. Y. Peng, A. Nanayakkara, M. Challacombe, P. M. W. Gill, B. Johnson, W. Chen, M. W. C. Wong, C. Gonzalez, J. A. Pople, Gaussian 03, Revision C.02. Gaussian, Inc.,Wallingford CT. (2004).

9. A.D. Becke, Density functional thermochemistry III, The role of exact Exchange, J. Chem. Phys., 98, (1993), 5648-5652.
10. R. G. Pearson, The electronic chemical potential and chemical hardness, Journal of molecular Structure: Theochem, 255 (1992) 261.

11. R. G. Parr, L. Szentpaly, S. Liu, Electrophilicity Index, J. Am. Chem. Soc.,121 (1999) 1922.

12. O. Trott, A. J. Olson, AutoDock Vina: Improving the speed and accuracy of docking with a new scoring function, efficient optimization, and multithreading, J. Comput. Chem., 31 (2010) 455.

13. Y. Kaya, V. T. Yilmaz, T. Arslan, O. Buyukgungor, Experimental and theoretical DFT studies of structure, spectroscopic and fluorescence properties of a new imine oxime derivative, Journal of Molecular Structure, 1024 (2012) 65-72.

14. T. J. Beaula, P. Muthuraja, M. Sethuram, M. Dhandapani, V.K. Rastogi, V. Bena Jothy, Biological and spectral studies of O-Tolyl Biguanide: Experimental and theoretical approach, J. Mol. Struct. 1128 (2017) 290.

15. R. Satheeshkumar, R. Shankar, W. Kaminsky, S. Kalaiselvi, V.V. Padma, K.J.R. Prasad, Theoretical and experimental investigations on molecular structure of 7-chloro-9-phenyl-2,3-dihydroacridin-4(1H)-one with cytotoxic studies, J. Mol. Struct. 1109 (2016) 247.

16. S. Jaime-Figueroa, A. Zamilpa, A. Guzma'n, D. J. Morgans,Jr., N-3-Alkylation of uracil and derivatives via N-1-boc protection, Synthetic Communications, 31 24 (2001) 3739-3746. 